\title{
ADOPTING IDEAS FROM CURRENT NORDIC TEACHER EDUCATION STRATEGIES TO INITIAL SCIENCE TEACHER EDUCATION
}

\author{
Jari Lavonen \\ University of Helsinki, Finland
}

\begin{abstract}
A key goal of initial teacher education in all countries is to educate quality teachers through a quality postsecondary programme and then support them in their careers through professional learning. However, there are different definitions and interpretations of a quality teacher or a quality teacher education programme. Several terms are used to describe a quality teacher, such as professional, effective, competent, expert, or ideal (Stronge \& Hindman, 2003; Goel, Bell, \& Little, 2008). Furthermore, the definition of a quality teacher changes continuously and follows the current trends of society and working life. Consequently, national-level teacher education strategies and teacher education programmes are continuously improved. In the Nordic region, all countries have been developing initial teacher education at the national and institutional levels over the last five years. In this editorial, I will briefly analyse the aims of new Finnish, Norwegian, and Swedish national-level teacher education strategies. Then I will briefly discuss how we can improve science teacher education according to the new strategies.

The Finnish Teacher Education Development Program 2017 was designed by 70 experts from universities and applied universities, the Ministry of Education and Culture, and representatives from the Association of Finnish Local and Regional Authorities, the Teacher Union, the Student Union, and the Principal Association (MEC, 2016). While designing the program, research outcomes related to teacher education were analysed and a national brainstorming exercise related to the renewal of teacher education was organised. Several local and nationwide meetings were also organised. According to the development programme, a professional teacher should first have a broad and solid knowledge base that comprises knowledge of pedagogy and a particular subject. This knowledge base include communication skills and skills needed in producing and consuming research-based knowledge. Knowledge base is needed, for example, in planning, implementation and in evaluation of students' learning outcomes and in supporting the students to learn generic competencies. Second, a teacher should be able to generate novel ideas, educational innovations and design the local curriculum. The teacher should also be able to plan inclusive education initiatives and design and adopt pedagogical innovations. Moreover, the teacher should interact with local municipal stakeholders. Third, a teacher should have the competencies required to develop their own and their school's expertise, especially regarding networks and partnerships with students, parents, and other stakeholders. Compared to previous national programmes or strategies, the new Finnish national-level strategy emphasises the competencies needed to generate novel ideas and educational innovations and, moreover, position the school as a learning community.

The framework for the Norwegian 2016 teacher education strategy aims to raise Norwegian teacher credentials to the master's level and augment what is expected of teachers. In addition to traditional pedagogical competencies, the strategy calls for teachers to 'take responsibility for developing and leading inclusive, creative, safe, and healthy learning environments' in the classroom. It also expects teachers to have the competencies needed to contribute to the professional community of teachers and to'contribute to both colleagues and the school's professional and organizational development' (Norwegian Directorate for Education and Training, 2017). Compared to previous na-
\end{abstract}


ISSN 1648-3898/Print/

ISSN 2538-7138/Online/

tional strategies, the new Norwegian strategy emphasises a research orientation in teacher education-'academic knowledge and knowledge on scientific thinking and research methods'-along with improved competencies in teacher collaboration, personal development, and school-wide development.

In Sweden as in Norway, a renewal of teacher education aims to update educational requirements to the master's level (Swedish Council for Higher Education, 2017). According to Swedish documents, to obtain a Master of Arts or Science in secondary education, the student shall demonstrate the competencies needed to participate autonomously in the teaching profession by acquiring 'the knowledge and skills required to work autonomously as a subject teacher in the specialisation.'The student shall also demonstrate the competence needed to develop learning environments - the 'capacity to create conditions in which all pupils can learn and develop.'The student shall also demonstrate the competencies need to develop the school environment, including 'the capacity to plan, implement, evaluate and develop teaching and educational processes individually and together with others.'

Of course, in the context of science teacher education, the new Nordic national-level strategies emphasise subject matter knowledge and the pedagogical skills needed to support various learners in the classroom so they can learn scientific knowledge and practices. Classroom teaching should also support the learning of generic competencies.

The Finnish teacher education programme has emphasised research orientation since the 1970s. Swedish and Norwegian strategies have now started to emphasise this research orientation. A science teacher needs research orientation in the professional learning of new science subject matter and pedagogical knowledge. A new characteristic in these three teacher education strategies is the emphasis on the competencies science teachers need to design versatile learning environments, interact with society, and develop inclusive classrooms in collaboration with other teachers. Science teachers should be willing and competent in their own professional learning, and they should be supportive of the learning of their colleagues. These new competencies, outlined in the national strategies, could be supported, for example, by having students collaborate in small groups in which they engage in active learning or knowledge-building and follow educational science knowledge practices, such as asking questions, planning and conducting small-scale educational research, and communicating the outcomes of their projects. Moreover, the construction of various instruments, such as research plans, concept maps, designs for a future school or physical and virtual science learning environment, helps students in their collaboration and in developing the competencies they need in a science teacher's learning community.

\section{References}

Goe, L.., Bell, C., \& Little, O. (2008). Approaches to evaluating teacher effectiveness: A research synthesis. Washington, DC: National Comprehensive Center for Teacher Quality.

Ministry of Education and Culture. (2016). Opettajankoulutuksen kehittämisohjelma [Development program for teachers'-re-and in-service Education]. Retrieved from https://minedu.fi/artikkeli/-/asset_publisher/opettajankoulutuksen-kehittamisohjelmajulkistettiin-opettajien-osaamista-kehitettava-suunnitelmallisesti-lapi-tyouran.

Norwegian Directorate for Education and Training. (2017). Forskrift om rammeplan for grunnskolelærerutdanningene for 1.-7. trinn og 5.-10. trinn. Oslo: Norwegian Directorate for Education and Training. Retrieved from https://www.regjeringen.no/cont entassets/6a4066c77c3c45b08044487d8a571a8f/forskrift_rammeplan_grunnskolelaererutdanningene.pdf.

Stronge, J. H., \& Hindman, J. (2003). Hiring the best teachers. Educational Leadership, 60, 48-52.

Swedish Council for Higher Education. (2017). Qualifications Ordinance. Stockholm: Swedish Council for Higher Education. Retrieved from https://www.uhr.se/en/start/laws-and-regulations/Laws-and-regulations/The-Higher-Education-Ordinance/ Annex-2/.

Jari Lavonen

PhD, Professor, Department of Education, University of Helsinki, PL 9

(Siltavuorenpenger 5A), 00014, Helsinki, Finland.

E-mail: jari.lavonen@helsinki.fi

ORCID: 0000-0003-2781-7953. 